\title{
Biosecurity and the ecologies of conservation. An anthropology of collecting practices among virus hunters and birdwatchers
}

Biossegurança e ecologias da conservação: uma antropologia das práticas de coleção entre caçadores de vírus e observadores de pássaros

Frédéric Keck ${ }^{*}$

* Laboratoire d'anthropologie sociale - Paris, France keck.fred@gmail.com https://orcid.org/0000-0002-7711-7288 


\begin{abstract}
This article describes prevention and preparedness as different techniques to conserve the past in order to anticipate the future. It relates the emergence of virology and ornithology to the places where samples are accumulated and classified. It then traces the role of anthropology in museums where cultural artifacts are conserved, to reflect on the possible interactions between microbiologists, birdwatchers and anthropologists in the field. It also asks questions about the position of China as a lack or an empty space in the global collections of museums.
\end{abstract}

Keywords: preparedness; conservation; museums; biosecurity.

\title{
Resumo
}

Este artigo descreve a prevenção e a preparação como diferentes técnicas para conservar o passado e antecipar o futuro. Ele relaciona o surgimento da virologia e da ornitologia com os locais onde as amostras são acumuladas e classificadas. Em seguida, o artigo traça o papel da antropologia em museus, onde artefatos culturais são conservados, para refletir sobre as possíveis interações entre microbiologistas, observadores de pássaros e antropólogos em campo. Por fim, o artigo também faz perguntas sobre a posição da China como ausência ou espaço vazio nas coleções globais dos museus.

Palavras-chave: preparação; conservação; museus; biossegurança. 
In the last ten years, I have been investigating the research led by microbiologists on avian influenza in south China, and particularly in Hong Kong where the H5N1 virus has emerged in 1997, killing two thirds of the persons it infects, and considered as one of the candidates for the next pandemic. To understand this research, I have argued with a group of anthropologists that we need to distinguish between the rationality of prevention, which calculates risks on a territory based on the series of numbers built by statistics, and the rationality of preparedness, which mitigates an unpredictable yet catastrophic event through the enactive imagination of its effects in vital infrastructures (Collier; Lakoff; Rabinow, 2004; Lakoff, 2017). While most of my colleagues working on pandemic preparedness have looked at how microbiologists ally with public health authorities and pharmaceutical industries to produce what Carlo Caduff (2014) has called "pandemic prophecy", I have focused on the alliance between microbiologists and birdwatchers to follow pathogens as they mutate between species. There were at least three reasons for such a shift in focus.

The first was ethnographic. I found it easier and more fun to spend time with birdwatchers than with hospital managers, because they would take a day off to lead me to bird reserves and teach me the names of birds while talking about the environmental struggles in which they were engaged, whereas public health officials had a lot to hide (despite official transparency) and no time to lose talking to an anthropologist.

My second reason was political. Coming from biosecurity studies that show how a public problem is framed through standardized techniques of preparedness (simulating epidemics and stockpiling masks drugs and vaccines following the model of a terrorist attack), I found it interesting to link the short temporality of emergency and crisis with the long temporality of ecological damage and rescue. In other words, working with birdwatchers allowed me to shift from biosecurity to biodiversity as a public problem that engages me as an observer and as a thinker.

The third reason was theoretical, which means, borrowing the term to Louis Althusser, a political choice I made within the academic field. Looking at the alliance between microbiologists and birdwatchers with the methods of an anthropology of the contemporary I learnt from Paul Rabinow $(1999,2003)$, I became sensitive to the analogies between their modes of reasoning and acting in their natural environment and those of hunters as described by more classical 
anthropologists such as Philippe Descola (2013). I then decided to follow the "ontological turn" because it allowed me to take seriously what microbiologists and birdwatchers told me about birds. They follow them, they catch them and transform them into specimens, they see invisible entities which provide meaning to their flight, they gain authority by solving public problems through their knowledge about birds. In short, I decided to take seriously the metaphor of "virus hunters" often applied to microbiologists, and to delve into the complex relation birdwatchers have with bird hunters. What if we consider problems of biosecurity and pandemic preparedness from the perspectives of hunters?

The problem of pandemic preparedness has been mostly raised, in the words of Michel Foucault $(2000,2007)$, as a pastoral problem. Given the fact that modern states want to increase the health of their population through infrastructures of care and statistical knowledge, how can we do to avoid them acting too much? What is the good combination between a power to "make live" and a power to "make die", particularly visible in the massive cullings of birds that gave modern states the opportunity to reaffirm their sovereignty at a time of uncontrolled circulation of living beings? I suggest, following the inspiration of Claude Lévi-Strauss $(1966,2016)$, to frame it as a cynegetic problem. Given that humans and birds share the same pathogens, what are the good conditions of communication between humans and birds to avoid infection and contagion? How can humans kill and eat birds without being infected by them as a revenge? I have argued that microbiologists and birdwatchers act as shamans in charge of solving or at least attenuating the contradictions faced by humans when they transform living beings into commodities in order to eat them.

This hypothesis has led me to emphasize the concept of sentinel that was used by microbiologists to describe their specific relation with birds in Hong Kong. The three main actors of my ethnography, Kennedy Shortridge, Malik Peiris and Guan Yi (2003, p. 70), declared just after the success of the battle against SARS when they had identified and contained a new virus in its animal reservoir: "The studies on the ecology of influenza led in Hong Kong in the 1970s, in which Hong Kong acted as a sentinel post for influenza, indicated that it was possible, for the first time, to do preparedness for flu on the avian level." The concept of sentinel defines here a territory where signs of future pandemics are captured on animals so that the alarm is raised for humans - much as the canary in the coalmine used during the $19^{\text {th }}$ century in Europe and the US. 
But it also designates unvaccinated chickens at the entrance of the farm signaling the presence of flu viruses in the farm by dying or by seroconverting (Keck; Lakoff, 2013). Finally, according to microbiologists versed in immunology, we all have sentinel cells in our organisms which come to encounter new microbes to check if they are dangerous or not (that is, known or unknown) and raise alert to the rest of the immune system so that an adequate response is found (Steinman; Cohn, 1973). A these three levels, sentinels act as catalysts of relations between self and other.

In my research I have asked how living beings become sentinels for other living beings, be it at the level of a political territory, of a poultry farm or of a living organism. I have asked what kind of signals are produced on this threshold between living beings, and how they can produce a peaceful communication between beings rather than a crisis communication. This doesn't mean that I endorse an enchanted view of the work of microbiologists as contemporary shamans: rather, I develop their own critics of the excesses of pandemic preparedness, showing that they borrow traits to the critics addressed by hunters to pastoralist societies. In short, I consider the distinction between virus hunters and those Carlo Caduff (2015) has called microbe farmers as a critical site to make a diagnostic of the failures and potentialities of pandemic preparedness.

This hypothesis has been enforced by the last five years I spent as a participant observer at the musée du quai Branly in Paris. Thinking about museums through the concepts of science studies and material culture, I became more and more sensitive to the fact that the microbiologists and birdwatchers I had worked with in Hong Kong were not only hunting birds but also collecting them. To borrow the terms of Australian historians of science Warwick Anderson (2008) and Tom Griffiths (1996), microbiologists act as contemporary huntergatherers when they accumulate samples from the past to imagine the future, and they act as curators when they organize these samples as information available to the public in order to share their imaginary of the future. This has led me to focus my reflection on the notion of "avian reservoir" defined as the ecosystem in which influenza mutate asymptomatically before transmitting to humans, sometimes using the mixing vessel of pigs. A pastoralist view of this notion would criticize the fact that Asian populations are described by public health authorities as living in too much proximity with their chickens and pigs; and indeed, "avian reservoirs" sounds like a stigmatization of "Asian people" 
as a "reservoir for viruses", in a new version of what Lévi-Strauss (1955) called "les tropiques bondés" by contrast with the "tropiques vides" of Amazonian forests. But I want to take a cynegetic view of avian reservoirs to conceive them precisely as an Amazonian forest, that is, as a space where human and nonhuman animals are connected by invisible entities called microbes, which can be captured, classified and mapped.

To do that, I want to show that avian reservoirs have been conceived in Asia as the equivalent of bird reserves and museums, and that this equivalence can be conceived by anthropologists precisely because anthropologists also spent time collecting and classifying human and non-human specimens. I argue, therefore, that cynegetic reasonings and practices are common to microbiologists, birdwatchers and anthropologists when they build natural reserves as museums for the conservation of the past and the imagination of the future, and that this explains the encounter between microbiologists, birdwatchers and an anthropologist on a Chinese sentinel post at the beginning of the $21^{\text {st }}$ century. I will thus consider in this article a parallel genealogy of virology, ornithology and anthropology from the perspective of museums considered as avian reservoirs.

\section{Museums of virology}

The framework of the museum was applied to the research on influenza by the World Health Organization after the Second World War. This research had burgeoned in the interwar period, connecting microbiologists and epidemiologists to understand the mechanisms of the 1918 "Spanish flu" and the cyclical character of flu pandemics. The first isolation of a flu virus in a British laboratory in 1933, by inoculating ferrets with human mucus, was deemed successful because, by contrast with other experimental models, ferrets sneeze as humans, their temperature rises and their nose runs when they have the flu. Transferring influenza viruses from the clinic to the lab through animal models allowed microbiologists to compare them and organize their visibility, thus shifting from symptoms of a current disease to signs of future pandemics.

The US Army set up a Commission on Influenza in 1941 headed by Thomas Francis, who had confirmed the British isolation of the influenza virus with the 
support of the Rockefeller Foundation. Among this team was a young virologist named George Hirst, who had discovered a technique to identify whether a flu virus was present in a human sample. Hirst (1941) had exposed a chicken egg containing a living eleven-day embryo with a flu virus, and observed that the red blood cells of the embryo were sticking together as if to defend themselves against the virus, a reaction he called agglutination and which was later reframed as hemagglutination. This discovery allowed Hirst to design a test (called HI assay), which combined the injection of flu viruses with the injection of human serum containing antibodies in a chicken embryo, and measured the antigenic differences between viral strains. The experimental model in the lab thus made visible and explained the obstacle faced by clinicians and epidemiologists: influenza viruses were constantly mutating, which made it difficult to design a vaccine for the next strains of influenza based on existing strains. If the difference between human strains was visible in chicken embryos in the lab, it became possible to prevent future pandemics by adapting vaccines to the distance between strains. Flu viruses were consequently classified by the surface protein that commanded the hemagglutination when the virus enters the cell, called $\mathrm{H}$, before another surface protein called neuraminidase $(\mathrm{N})$ was identified in the 1960's as playing a major role in the release of the virus from the cell, and then became a target for antivirals such as Relenza. Hence the names given to influenza viruses: H1N1, H2N2, H3N2, H5N1...

The World Health Organization benefited from these discoveries to proclaim after the war that influenza viruses from all over the world should be compared to adapt vaccines and prevent the next pandemic. In 1948, the Centre for Influenza Research of the WHO defined itself as a "museum" for flu virus strains, and asked laboratories to send them in a dessicated form. Notice the difference between a repository and a museum: while a repository contents itself with storing and conserving materials, a museum has to classify and inventory this material, but also to make its differences visible by displaying them to the public.

The dessicated viruses received by the Centre, will, as far as possible, be tested to determine their activity and, where appropriate, passaged to form a larger stock of dessicated material. It will thus constitute a sort of "museum" of dessicated strains of influenza. All laboratories that conduct research on the antigenic 
relations between strains may request the Centre to be kept informed of available strains and obtain the sending of a particular strain. We will periodically submit the museum strains - or at least those which seem to be important and representative - to passages in eggs or others to maintain stocks and avoid losses. (quoted in Aranzazu, 2015, p. 46).

The technique of egg passaging designed by George Hirst was thus applied by the WHO Centre for Influenza to dessicated strains they received from labs, and in return laboratories from all over the world could compare the strains they received from clinics to reference strains. Just as art museums were being redefined by the International Council of Museums of UNESCO in 1945 as places where works of art were conserved and should circulate through temporary exhibitions, virology laboratories were redefined by WHO as places where flu viruses should safely circulate after major outbreaks before being compared at a central level. Virologists became the managers of a global circulation of viral strains, while a massive industry of chicken eggs, killing billions of chicken embryos, made possible this global production of knowledge, as the invisible working force underlying the visibility of the museum.

A major shift occurred at the end of the 1970's in influenza research, revealing the flaws of this dream of a universal museum of flu strains set up by WHO. The emergence of an H1N1 "swine flu" virus in the US - possibly from a "Spanish flu" virus released from a Soviet lab - triggered a massive campaign of vaccination after the death of a soldier in Fort Dix from this new virus in 1976. This campaign, known as "Swine Flu Fiasco" (Neustadt; Feinberg, 1983), was interrupted when $10 \%$ of the population had received the vaccine and more than 500 cases of Guillain-Barre syndromes were declared. This event showed the difficulties of preventing the next pandemic with vaccines based on the differences between strains. It also revealed that circulating flu viruses between labs was not neutral since virus strains, when they are alive, can escape from the labs and replicate in the population to cause new pandemics, which led to increasing concerns about bioterrorism after the end of the Cold War.

Another parallel event changed the strategy of the museum of viral strains. In 1976, the WHO opened an Expert Committee on the Ecology of Infectious Diseases under the leadership of its Chief Veterinary Officer, Martin Kaplan (Vagneron, 2015). The role of this committee was to anticipate the emergence 
of new pathogens from animal reservoirs where they mutate. Among the key members of this committee were Graeme Laver and Robert Webster, who had set up a bank of influenza virus strains by collecting bird feces all over the world with the support of Martin Kaplan, but also Kennedy Shortridge, who had just opened the Department of microbiology at the Faculty of Medicine of the University of Hong Kong. Shortridge's idea was that since China was not part of WHO, and although major flu pandemics originated from south China which he considered an "influenza epicentre" (Shortridge; Stuart-Harris, 1982), there was very little knowledge on the flu strains circulating in China. Hence Hong Kong should become a sentinel where flu strains could be collected, compared and sent to WHO to contribute to the global museum.

These two events can be described as operating a shift from prevention to preparedness in the strategy of WHO as a museum of flu strains. The first event showed that the circulation and comparison of flu strains raise safety issues, as viruses have a life of their own which cannot be reduced to the distances between antigenic forms: they mutate, reassort, escape, trigger unexpected immune responses... The second event revealed that a large part of the global circulation of flu viruses remained unknown, because nation-States such as China refused to provide them, or simply because they didn't have the means to collect them. As Luc Boltanski and Arnaud Esquerre (2016) recently showed, when there are gaps in a collection, strategies must be found to cover these gaps. The invention of stockpiling vaccines was a response to the first event, and the implementation of sentinel devices was a response to the second. If the next flu pandemic could not be prevented based on the comparison between existing flu strains, it became necessary to prepare for it by capturing early warning signals to mitigate the consequences of the outbreak.

Simulation of pandemics thus became the major technique of influenza management at WHO. This became possible through Genbank, which has allowed virologists to compare in real-time a new strain to existing strains based on their genetic sequences, and to imagine through bioinformatics softwares where this new virus comes from and how it could evolve. Bruno Strasser (2019) has showed how Genbank has changed what he calls "the moral economies of biomedicine". Rather than replacing $18^{\text {th }}$ century natural history, Strasser argues, experimental biology has rearticulated its method of building collections in a centre reflecting the diversity of the world. While natural 
history collections displayed the power and wealth of those who accumulated them, Strasser argues that contemporary databases have reorganized this modern dream of the collection through a new moral economy of science, around the participation of all citizens to the production of science. The organizer of the database should not be the owner of the collection, but the manager of a collective effort in which every individual initiative is valorized. This idea of participative science through the use of databases is also very strong in ornithology, to which I now turn.

\section{Museums of ornithology}

The emergence of ornithology as a science of collecting and classifying birds has two causes: the Industrial Revolution, which led British naturalists to return to the countryside with a new gaze on ordinary birds (such as Gilbert White in his famous Natural History and Antiquities of Selborne published in 1789), and the travels around the world, which led to the accumulation in England of specimens of exotic birds (Bargheer, 2018). Joseph Banks, a botanist who later succeeded Isaac Newton as the head of the Royal Society, took part to the first travel of captain Cook in the Pacific Ocean between 1768 and 1771, and brought back 500 bird specimens and 32 drawings which he sent to the British Museum. The founder of British ornithology, John Latham, trained in anatomy and member of the Royal Society after 1775 , consulted the bird collections sent by Joseph Banks at the British Museum as well as the cabinet of curiosities of Ashton Lever, which also contained specimens from the Cook voyages. He published A General Synopsis of Birds between 1781 and 1785, applying Linnaeus' systematic classifications as well as the division between land and water birds proposed by John Ray. As the specimens from Cook's travels rapidly turned into decay, particularly in Lever's cabinet, the handbook published by Latham secured the knowledge about bird diversity. While the cabinet of curiosities displayed birds for their extraordinary aspects, without much care for their materiality, ornithology museums defined the rarity of a bird species in relation to the whole collection, and conserved its materiality accordingly.

For ornithology museums, the vulnerability of bird materialities (not only the fragility of their skeletons, the organicity of their skins but also the colours 
of their feathers) was a major problem, faced by the new profession of taxidermy. Since museums were conceived as repositories of knowledge about bird diversity, this rapid decaying reminded ornithologists of the ambivalence of killing birds. American ornithologists were particularly sensitive to this ambivalence, because they were first animated by a feeling of abundance of wildlife in the territory of their young nation, before discovering that many bird species became extinct after massive hunting campaigns (Barrow, 2009). The first curator in ornithology at the Smithsonian Institution, Robert Rigdway, was passionate of reading books as well as of hunting birds. His biographer, Daniel Lewis, writes that his "study of birds (was) largely initiated by sighting carefully down the barrel of a gun." John Muir described him as having "wonderful bird eyes, all the birds in America in them." (Lewis, 2012, p. 54, 63) By contrast with Audubon, who was mostly concerned with observing and drawing the birds of North America in their habitat, Rigdway was obsessed with classifying, conserving and exchanging bird specimens in the museum.

The dream of a complete classification of living beings following Linnaeus and Darwin's principles is expressed in this definition of science by the American Naturalist in 1882: "a rationally established system of facts and ideas, which, over a given range of objects, confers certainty, assurance, probability, or even a doubt that knows why it doubts." (Lewis, 2012, p. 85) The museum then became a place to foresee the future evolution of life by considering series of past cases. The evolutionary theory was a criteria to give value to the materiality of bird samples. It allowed curators to hierarchize their stocks of specimens following lines of supposed descent, and thus to select among all the specimens available those who had more value than others. Small birds were consequently preferred to big birds by curators, not only because they were less difficult to store, but also because they often filled the gaps in collections and were easier to exchange with private collectors who didn't valorize them.

Yet the materiality of birds' life and death returned in this system of ideas through the challenges of their decay. Lewis (2012, p. 135) notes that naturalists of the museum constantly expressed depression in the summer months, which he explains by the fact that arsenic was used in this month to prevent rotting of the skins and insects infestation. A new preventative against insects and skin deterioration, Maynard's Dermal Preservative, became popular in 
ornithology museums in the 1880's because it also protected the hands of curators from arsenic poisoning. Curators who took care of bird specimens through the ideal hierarchy of evolutionary systems thus suffered from the same troubles that affected the materialities of bird skins, and could take the perspectives of birds on their own decay. This lead to a crisis of the natural history museum when awareness grew in the 1930's that birds collected in their environment became extinct. Caring for dead birds in museums was not enough: they needed to be protected in their natural habitat.

The global politics of ornithology after the Second World War was in many ways a reaction to the failures of national projects of bird conservation. Under the supervision of the International Union for the Conservation of Nature (IUCN), lists of endangered species were written to rule the exchanges of natural specimens between natural history museums and wildlife reserves. While it seems that wildlife reserves replaced natural history museums as sites to practice ornithology, it may be argued that these reserves were managed as museums, that is, as sites where the diversity of living forms should be monitored (Vidal; Dias, 2016). In 1946, Peter Scott opened the Wildfowls and Wetland Trust in Slimbridge to shelter all wildfowl species of the world in Britain. He founded the World Wildlife Fund in 1961 to provide money for conservation projects, and particularly to the IUCN, and set up the red list of endangered species. Birds were not valued any more as specimens filling gaps in a collection, but as "indicator species" in a trend to extinction (Moore, 1973). Ornithology museums and wildlife reserves have thus gradually shifted from a paradigm of prevention, with a theory of evolution that made series of bird species meaningful, to a paradigm of preparedness, with scenarios of extinction in which the fate of humans and non-humans is imagined through indicator species.

IUCN has thus played a role in natural history comparable to that of WHO in public health, by redefining the meaning and value of birds and viruses globally with a new challenge to prepare for future threats. It must be stressed that, as in the research on influenza, China has taken a central position in this new economy of knowledge. If the most colorful birds were collected in Amazonia and Polynesia in the $18^{\text {th }}$ century, China appeared in the $19^{\text {th }}$ century as a reservoir of new species, with around 1000 bird species over 8000 known globally. Robert Swinhoe, a British diplomat, observed birds in Fujian 
and Taiwan, while Armand David, a French missionary, was traveling in Central China. Both used local hunters to collect specimens they sent to museums of natural history in London and Paris (Boutan, 1993; Fan, 2004). They also trained Chinese curators to prepare specimens and display them in museums, thus challenging what they thought was the Chinese tradition of looking at a bird only for its flesh or its song. When members of the Factory of Canton thus proposed to create a British Museum in China at the end of the 1820's, they argued: “Considering the taste of the Chinese for live Birds and Fishes, we may hope that the richer Classes may acquire a taste for the same Animals when prepared for the Cabinet." (quoted in Peckham, 2014, p. 132). Indeed, Wang Shu-hang, who had worked with Father Armand David to collect specimens in Central China, became the taxidermist at the Shanghai Museum founded in 1874.

In 1957, British officers created the Hong Kong Birdwatching Society. They practiced birdwatching with binoculars while overseeing the border between Hong Kong and mainland China to prepare for a potential attack from the People's Liberation Army. Between 1963 and 1971, they took part to the Migratory Animal Pathological Survey, a program launched by American ornithologist Elliot McClure (1974) to study migratory birds and their migrations between Japan and Thailand, training birdwatchers how to catch and release a bird after collecting samples and putting a ring on its legs, and the centre for sending the informations gathered through this program was Hong Kong. In 1997, when Hong Kong returned under Chinese sovereignty, the Hong Kong Birdwatching Society became predominantly Chinese, under the leadership of the head of the Hong Kong Observatory Chiu Ying Lam, and the main association for nature protection in Hong Kong with 2000 members. It became a model for birdwatching societies that were created all over mainland China, teaching them how to observe and classify birds, but also how to mobilize to defend a natural habitat threatened by a construction project (Keck, 2015).

Hong Kong and China thus played a central role in the repositioning of ornithology from a predictive science, illustrating the laws of Darwinian evolutionism, to techniques of preparedness, anticipating future extinction by caring for bird specimens in museums and live birds in natural reserves. If anthropology can diagnose this shift, it is because it has met it in its own practices of collecting in ethnographic museums. 


\section{Museums of anthropology}

While debates about preparedness often turned around its capacity to predict an event that never happens, I focus in this article on the vital infrastructures of collecting that made these predictions possible. Working in a museum has allowed me to question the value of prophetic claims on bird flu not by focusing on the future events that they predicted but by looking at the living beings they transformed in the present. Anthropologists can work with microbiologists and ornithologists on the same footing when dealing with avian influenza because they share the same genealogy of museums, that is, a form of accumulation which produces knowledge by connecting a center with its peripheries (Alpers, 1991; Rabinow, 2012). Tracing the history of past accumulations that have made knowledge possible to anticipate the future allows these professions to understand how they can curate the present, that is, display their objects in a critical way that is both meaningful and careful. I now want to describe how the shift from prevention to preparedness affects the museums in which anthropologists think and work.

The musée du quai Branly was created in 1996 by President Jacques Chirac merging two different types of collections: those of the former Museum of Man and those of the Museum of Arts from Africa, America and Oceania. The genealogy of these two collections must be drawn separately to understand the problems raised by their fusion.

The Museum of Man was created in 1938 by Paul Rivet and Georges-Henri Rivière with the former collections of the Musée d'Ethnographie du Trocadéro. It contained artifacts coming from gifts to the royal cabinets (mostly from America), bounties of imperial expeditions (mostly from the Pacific) as well as skulls for republican phrenology (mostly from Africa). Specialized in south American cultures and languages, co-founder of the Institute of Ethnology of the University of Paris with Lucien Lévy-Bruhl and Marcel Mauss in 1928, Rivet promoted ethnographic missions through which objects would be collected, documented and stored, such as the famous mission Dakar-Djibouti organized by Marcel Griaule between 1931 and 1933, or Claude Lévi-Strauss' expeditions in Amazonia in 1935 and 1938. The Musée de l'Homme presented itself as a repository where all cultures of the world could be studied through the ethnographic artifacts conserved in Paris. It was both a laboratory for the 
information contained in the artifacts and a space of exhibition for the aesthetic values of these objects.

Rivet allied with Rivière to display his collections following the new taste for "primitive art" developed by Surrealist artists. Both of them were key actors of the International Council of Museums (ICOM), a section of the UNESCO which played after 1945 a similar role for anthropology to that of WHO for virology and IUCN for ornithology. Rivière was appointed director of ICOM between 1948 and 1965, and between 1937 and 1967 he became the head of the museum of European folklore named Musée des Arts et Traditions Populaires. Rivet was one of the strongest supporters of the role of museums in public education and scientific research at the ICOM, although his socialist commitment and his faith in human progress were tarnished at the end of his life by his refusal of the independence of Algeria (Gorgus, 2003; Laurière, 2008).

The Museum of Arts from Africa, America and Oceania was created in 1969 by André Malraux, who thus concluded his ten-year support of General de Gaulle after the communist anti-colonial engagement of his youth. Under the presidency of De Gaulle in 1959, Malraux had created a Minister of Culture separated from the Minister of Education, arguing that education was addressed to the minds while culture was addressed to the hearts. He promoted the idea of an imaginary museum (Malraux, 1947) whereby all cultures of the world would communicate affectively, in rupture with the structuralist conception of cultures developed at the same time by Claude Lévi-Strauss at the Collège de France. The ethnographic collections displayed at the Porte Dorée, on the site of the former Museum of Colonies, were supposed to trigger universal feelings in the visitor, such as the fear of the sacred or the desire for human origins.

Placed under the double sponsorship of the Minister of Culture and the Minister of Research, the musée du quai Branly results from the conflict between these two perspectives on ethnographic artifacts. With its 300000 objects and 500000 documents, it is one of the biggest museums of "nonWestern art" or "world cultures", but it escapes the framework of all other museums of anthropology. Most anthropologists, following the prominent voice of Louis Dumont, criticized the creation of the musée du quai Branly, because Jacques Chirac claimed that the idea of a "museum of primitive art" had been inspired to him by a collector and merchant of African art, Jacques Kerchache (Price, 2007). Claude Lévi-Strauss gave his support to this project because, he 
argued, the Museum of Man has not secured properly the conservation of ethnographic collections, and many artifacts had been stolen and sold on the art market. He declared: "I have always said and thought that museums are made first for objects and then only for visitors, even if I go against trendy ideas. The first function of museums is conservation." (Chiva, 1992, p. 159).

To fulfill this function in a contemporary way, the musée du quai Branly invested in two major technological innovations: securitization and digitalization. Architect Jean Nouvel conceived an open storage at the entrance of the museum for musical instruments and a closed storage underneath the museum for all the other artifacts. The closed storage is accessible to only two of the 400 persons working at the museum, who use digital recognition to open its doors. All the artifacts that have been acquired or that have been lent for temporary exhibitions enter the reserves through a room where oxygen is removed by a technique called anoxia, in such a way that the insects they contain die in a few days. The reserves are surrounded by a clay shell which is supposed to protect the artifacts from a flood of the river Seine. The digitalization of collections reverses this politics of restricted access. All artifacts of the collection are available on the Internet through a software called TMS (The Museum System), with documents on their origins and composition. Visitors who want to have access to the objects themselves have to require curators a few weeks in advance, and receive an appointment at the museum library. Virtual images of objects thus compensate for the difficulty to access the real objects themselves (Beltrame, 2012; Roustan, 2016).

The exhibitions displayed by the museum reflect this ambivalent politics of access. In the permanent exhibition, the masterworks of the collection are displayed in the dark with little information on labels or screens, to let the visitor experiment the mystery of these intriguing objects. Temporary exhibitions then shed light on some aspects of these collections by associating them with historical, aesthetic or philosophical arguments. If visitors have indirect access to the objects under a glass box in the exhibitions, these exhibitions play on different forms of lighting - in the material and intellectual sense - to trigger reflections on the diversity of cultures. While the permanent exhibition is organized as a "tour du monde", no general narrative is proposed that would bring definitive coherence to the diversity of artifacts. The musée du quai Branly presents itself as a polyphonous expression of globalization. 
This staunch refusal of the evolutionary narrative that was shared by anthropologists of the Museum of Man, and this assumed aesthetic of darkness inherited from the Museum of Arts from Africa, America and Oceania mark, in my view, a shift from prevention to preparedness. Ethnographic artifacts are not displayed in a narrative of progress where they would become meaningful as rare documents of the human species. They are considered as vulnerable materialities whose value has increased on the art market, and that must be conserved for their scientific, aesthetic and financial value. The musée du quai Branly faces not the threat of disappearance of the societies these objects come from, as the former Museum of Man based on a scenario of evolution from primitive to civilized societies, but the threat of destruction of the objects themselves and of the different values they contain, based on the scenario of extinction of the ecologies in which they are conserved.

Ethnographic artifacts are mostly composed with organic materials (wood, skin, skulls, feathers, saliva...) that can easily be degraded by their exposure to bacteria or to insects. Preventive conservation, which has been designed to calculate the time of degradation for the materials of classical European art such as wood or stone, thus needs to adapt to materials that were not conceived for storage in a museum. If ethnographic artifacts have been preserved beyond their expectancy of life by technologies of conversation, discussions on the duration of preservation involve political choices on the value of artifacts considered as national heritage and benefiting from these costly technologies. This is one of the main arguments in the debate on restitution of ethnographic artefacts to the societies they come from: they should be presented to a large number of visitors to justify the investment in their conservation. As artifacts are lended to other museums, an assessment of their state of preservation is made prior to the lending, to calculate the insurance cost of the lending. But insurance cannot cover catastrophic events such as their massive destruction by a natural disaster. As contested and vulnerable objects, ethnographic artifacts need to be displayed and secured at the same time to continue their social life as things. While James Clifford (1997) defined museums as "contact zones" to characterize their openness to fluxes of persons and goods in a post-modern world, they tend to be redefined as "spaces of contagion" by their circulation in the world of biosecurity.

Techniques of preparedness such as sentinels, simulations and stockpiling have thus been applied at the same time at the musée du quai Branly. The 
open storage of musical instruments at the entrance of the museum has been defined as a "hotspot" of infestation (Brown; Kelly, 2014) after a map of the presence of insects was built using a technology to record the ultrasounds they make when they crunch the wood, called "Requiem for xylophages". This map showed that the musical instruments near the cloakroom were more exposed to fleas carried by visitors. Musical instruments, with their low value on the market of tribal art, can thus be defined as sentinels for the threats that affect all the artifacts of the museum.

If infestation is a constant and minor threat, as it slowly erodes wooden objects, flood is an exceptional threat that is much more dreaded, as it could damage all objects composed of organic material as well as documents. Since a major flood of the river Seine is expected every century, exercises of evacuation of the collections happen every year, once for documents and once for artifacts. The staff of the museum is keen to participate to these exercises because it is one of the only opportunities for them to have direct access to the artifacts, which they move to the exhibition spaces as potential victims of disaster in need of care and support. Aside from these real-ground exercises of natural disaster, the musée du quai Branly also creates scenarios for digital applications enabling visitors to interact with objects: through enhanced reality, objects tell their stories from their creation to their arrival in collections, as if to exorcize the potentiality of their restitution.

In its program of contingency planning, the musée du quai Branly has classified its artifacts by order of priority for evacuation in case of a flood. Surprisingly, this order is not determined by the vulnerability of the materials to water exposure, but by the value of the artifacts on the art market. Thus, an expensive wooden statue from Africa would be ranked first for evacuation although it could certainly resist flood for a few hours, while a series of botanical herbs from Vietnam or sugar skulls from Mexico would be ranked third because they have a lower value on the art market. In that sense, we can describe the reserves as a form of stockpiling, and compare objects to vaccines depending on the strength of the immune response they trigger in those who observe them.

To conclude, I have argued in this article for a shift in the reflection on preparedness from the short temporality of emergencies to the long temporality of ecologies. While most genealogies of preparedness start with the emergence of $\mathrm{H} 5 \mathrm{~N} 1$ in 1997 in the global context of the war on terror and the turn 
to biosecurity in life science, I have developed three alternative genealogies on longer scales of temporality: first, the emergence of the H1N1 virus causing "Spanish flu" at the end of the First World War, giving rise to virology and epidemiology in the attempt to anticipate the next pandemic; second, the Industrial Revolution linked to the colonial expansion of Europe to the rest of the World, giving rise to ornithology and other natural sciences under the framework of Darwinism; third, the encounter between the first European explorers and the New World depicted as an abundance of wildlife in the $16^{\text {th }}$ century, giving rise to social anthropology as an attempt to encompass the most diverse forms of humanity. In these three scales of temporality, preparedness takes different meanings, as it doesn't involve only preparing for the next terrorist attack or the next natural disaster, but preparing for the destruction of the environments in which humans have co-evolved with other animals and with microbes, using birds as sentinel species announcing the next extinction and bird artifacts as stocks where signatures of the past and signs of the future are accumulated. While prevention now appears as a dream of presenting all the information about diverse ecologies in a general framework where the past and the future follow the same patterns, characterized by Philippe Descola (2013) as analogism and particularly illustrated by the post-war institutions such as WHO, IUCN and ICOM, we may have to turn to the resources of animistic rationalities inscribed in cynegetic practices of virus hunters to anticipate an unpredictable future by communicating with birds through data bases in which their signs become meaningful.

\section{References}

ALPERS, S. The museum as a way of seeing. In: KARP, I.; LAVINE, S. (ed.). Exhibiting cultures: the poetics and politics of museum display. Washington: Smithsonian Books, 1991. p. 25-32.

ANDERSON, $\mathrm{W}$. The collectors of lost souls: kuru, moral peril, and the creation of value in science. Baltimore: Johns Hopkins University Press, 2008.

ARANZAZU, A. I. Le réseau de surveillance de la grippe de l'OMS: circulation, innovation et santé publique. 2015. Thèse (Doctorat en Histoire) - Université Paris 13, Paris, 2015. 
BARGHEER, S. Moral entanglements: conserving birds in Great Britain and Germany. Chicago: The University of Chicago Press, 2018.

BARROW, M. V. Nature's ghosts: confronting extinction from the age of Jefferson to the age of ecology. Chicago: The University of Chicago Press, 2009.

BELTRAME, T. N. Un travail de Pénélope au musée. Décomposer et recomposer une base de données. Revue d'anthropologie des connaissances, v. 6, n. 1, p. 217-237, 2012.

BOLTANSKI, L.; ESQUERRE, A. Enrichissement: une critique de la marchandise. Paris: Gallimard, 2016.

BOUTAN, E. Le nuage et la vitrine: une vie de monsieur David. Biarritz: Atlantica, 1993. BROWN, H.; KELLY, A. Material proximities and hotspots: towards an anthropology of viral hemorrhagic fevers. Medical Anthropology Quaterly, v. 28, n. 2, p. 80-303, June 2014.

CADUFF, C. Pandemic prophecy: or how to have faith in reason. Current Anthropology, v. 55, n. 3, p. 96-315, June 2014.

CADUFF, C. The pandemic perhaps: dramatic events in a public culture of danger. Oakland: University of California Press, 2015.

CHIVA, I. Qu'est-ce qu'un musée des arts et traditions populaires? Entretien avec Claude Lévi-Strauss. Le Débat, v. 3, n. 70, p. 156-163, 1992.

CLIFFORD, J. Routes: travel and translation in the late twentieth century. Cambridge: Harvard University Press, 1997.

COLLIER, S. J.; LAKOFF, A.; RABINOW, P. Biosecurity: towards an anthropology of the contemporary. Anthropology Today, v. 20, n. 5, p. 3-7, October 2004.

DESCOLA, P. Beyond nature and culture. Translated by Janet Lloyd. Chicago: The University of Chicago Press, 2013.

FAN, F.-T. British naturalists in Qing China: science, empire, and cultural encounter. Cambridge: Harvard University Press, 2004.

FOUCAULT, M. Omnes et singulatim: towards a criticism of political reason. In: FAUBION, J. D. (ed.). Power: essential works of Michel Foucault 1954-1984: vol. 3. New York: The New Press, 2000. p. 298-325.

FOUCAULT, M. Security, territory, population: lectures at the Collège de France 19771978. Translated by Graham Burchell. London: Palgrave Macmillan, 2007.

GORGUS, N. Le magicien des vitrines: le muséologue Georges Henri Rivière. Paris: MSH, 2003. 
GRIFFITHS, T. Hunters and collectors: the antiquarian imagination in Australia. Cambridge: Cambridge University Press, 1996.

HIRST, G. The agglutination of red cells by allantoic fluid of chick embryos infected with influenza virus. Science, v. 94, n. 2427, p. 22-23, 1941.

KECK, F. Sentinels for the environment: birdwatchers in Taiwan and Hong Kong. China Perspectives, n. 2, p. 41-50, 2015.

KECK, F.; LAKOFF, A. Sentinel devices. Limn, n. 3, 2013. Available at: https://limn.it/ articles/preface-sentinel-devices-2/. Access: 15 May 2019.

LAKOFF, A. Unprepared: global health in a time of emergency. Oakland: University of California Press, 2017.

LAURIÈRE, C. Paul Rivet: le savant et le politique. Paris: Publications scientifiques du Muséum national d'histoire naturelle, 2008.

LÉVI-STRAUSS, C. Tristes tropiques. Paris: Plon, 1955.

LÉVI-STRAUSS, C. Savage mind. Translated by Julian Pitt-Rivers. London: Weidenfeld and Nicolson, 1966.

LÉVI-STRAUSS, C. We are all cannibals: and other essays. Translated by Jane Marie Todd. New York: Columbia University Press, 2016.

LEWIS, D. The feathery tribe: Robert Rigdway and the modern study of birds. New Haven: Yale University Press, 2012.

MALRAUX, A. Le musée imaginaire. Paris: Gallimard, 1947.

MCCLURE, E. Migration and survival of the birds of Asia. Bangkok: White Lotus Press, 1974.

MOORE, N. W. Indicator species. Nature in Focus, n. 14, p. 3-6, 1973.

NEUSTADT, R.; FEINBERG, H. The epidemic that never was: policy making and the swine flu scare. New York: Vintage Books, 1983.

PECKHAM, R. Game of empires: hunting in treaty-port China. In: BEATTIE, J.; MELILLO, E.; O'GORMAN, E. (ed.). Eco-cultural networks and the British Empire. New York: Bloomsbury, 2014. p. 202-232.

PRICE, S. Paris primitive: Jacques Chirac's museum on the Quai Branly. Chicago: The University of Chicago Press, 2007.

RABINOW, P. French DNA: trouble in the Purgatory. Chicago: The University of Chicago Press, 1999. 
RABINOW, P. Anthropos today: reflections on modern equipment. Princeton: Princeton University Press, 2003.

RABINOW, P. A contemporary museum. In: DELISS, C. (ed.). Object atlas: fieldwork in the museum. Kerber: Bielefeld, 2012. p. 7-8.

ROUSTAN, M. Des clefs des réserves aux mots-clefs des bases de données. Mutations du rapport aux objets pour les conservateurs du MAAO au musée du quai Branly. In: HOTTIN, C.; VOISENAT, C. (dir.). Le tournant patrimonial: mutations contemporaines des métiers du patrimoine. Paris: MSH, 2016. p. 117-139.

SHORTRIDGE, K.; PEIRIS, M.; GUAN, Y. The next influenza pandemic: lessons from Hong Kong. Journal of Applied Microbiology, n. 94, p. 70-79, 2003.

SHORTRIDGE, K. F.; STUART-HARRIS, C. H. An influenza epicentre?. The Lancet, v. 320, n. 8302, p. 812-813, 1982.

STEINMAN, R. M.; COHN, Z. Identification of a novel cell type in peripheral lymphoid organs of mice. Journal of Experimental Medicine, New York, v. 137, p. 1142-1162, 1973.

STRASSER, B. Collecting experiments: making big data biology. Chicago: The University of Chicago Press, 2019.

VAGNERON, F. Surveiller et s'unir? Le rôle de l'OMS dans les premières mobilisations internationales autour d'un réservoir animal de la grippe. Revue d'anthropologie des connaissances, v. 9, n. 2, p. 139-162, 2015.

VIDAL, F.; DIAS, N. Introduction: the endangerment sensibility. In: VIDAL, F.; DIAS, N. (ed.). Endangerment, biodiversity and culture. London: Routledge, 2016. p. 1-40.

Recebido: 12/12/2019 Aceito:10/01/2020 | Received:12/12/2019 Accepted: 1/10/2020 